\title{
A new tropical cyanobacterium Pinocchia polymorpha gen. et sp. nov. derived from the genus Pseudanabaena
}

\author{
Petr Dvořák ${ }^{1}$, Eva JahodÁR̆ovÁ ${ }^{1}$, Petr HašLer ${ }^{1}$, Evgeniy Gusev ${ }^{2}$ \& Aloisie \\ POULÍČKOVÁ ${ }^{1}$
}

\author{
${ }^{1}$ Department of Botany, Faculty of Science, Palacký University Olomouc, Šlechtitelů 11, CZ-783 71 Olomouc, \\ Czech Republic \\ ${ }^{2}$ Papanin's Institute for Biology of Inland Waters Russian Academy of Sciences, 152742, Borok, Russia
}

\begin{abstract}
Tropical cyanobacteria are an enigmatic group, often overlooked due to undersampling, yet expected to yield tremendous biodiversity. Many recent taxonomical studies have reported the existence of polyphyletic genera complexes in cyanobacteria (cryptogenera), where morphological coherent groups (often hardly distinguishable) have polyphyletic origins. In this paper, we employed a combined genetic and phenotypical approach to describe some newly isolated Pseudanabaena-like cyanobacteria from a lake in Vietnam. We found that two studied strains belonged to the monophyletic clade outside of the Pseudanabaena sensu stricto, thus it may be designed as a new genus, which has been called Pinocchia. However, there are only minor morphological differences from the other Pseudanabaena species. Thus, it may be considered as example of the cryptic genus. Moreover, it is additional evidence for a polyphyletic origin of the genus Pseudanabaena.
\end{abstract}

Key words: 16S rRNA, 16S-23S ITS, cryptogenus, new species

\section{INTRODUCTION}

Cyanobacteria are one of the most important and the oldest primary producers capable of oxygenic photosynthesis, which can be found in nearly all environments from polar to tropical areas (WhiтTon \& PotTs 2000).

The biodiversity of cyanobacteria has been studied more extensively in temperate zones, which may be demonstrated by the number of published papers involved in cyanobacterial diversity. Web of Knowledge database contains 9066 papers involved in diversity of cyanobacteria (database searched $26^{\text {th }}$ November 2014), from which only 280 papers investigated tropical cyanobacterial diversity. Moreover, new cyanobacterial isolates retrieved from tropical habitats often lead to description of new taxa (e.g. Fiore et al. 2007; HaŠLER et al. 2014; VACCARINO \& JoHANSEN 2011 and many others). Thus, the tropical biodiversity seems to be largely underestimated. A reason for that may lie in undersampling and very high, yet enigmatic, cyanobacterial diversity in tropical habitats.

The taxonomy and systematics of cyanobacteria has been undergoing substantial changes due to an employment of molecular markers (mainly $16 \mathrm{~S}$ rRNA). One of the chief concerns arises from the important problem of polyphyletic genera. For example, it has been noted that almost all Geitlerian genera (after
GeITLER 1932) have been confirmed using molecular markers. On the other hand, most of genera appear to be polyphyletic (КомÁReK 2010). Such a polyphyly might be extreme. For instance, DvoŘÁK et al. (2014a) noted 12 lineages within the genus Synechococcus sensu lato, which suggest frequent convergence in cyanobacteria. What might be the reasons for such entangled evolutionary relationships? Dvǒ̌́́K et al. (2014a) suggested that homologous recombination and horizontal gene transfer within local gene pools sensu Polz et al. (2013) provide a space for convergence of phenotypes, and therefore an existence of polyphyletic groups.

The genus Pseudanabaena (Lauterborn 1915) is widely distributed. According to KomÁrek \& ANAGNOSTIDIS (2005), Pseudanabaena represents filamentous, non-heterocytous, sheathless, cyanobacteria, usually with thin trichomes (up to $3.5 \mathrm{~mm}$ ), and often with cells connected by hyaline bridges. Members of the genus Pseudanabaena differ in the shape of apical cells and the presence of aerotopes, dividing the genus into three subgenera (Ilyonema, Skujanema, Pseudanabaena). There are likely several polyphyletic lineages within this morphotype, and likely more masked by cryptic diversity (ACINAS et al. 2009; Dvǒ̌́́K et al. 2014a). However, no extensive revision has been performed.

$16 \mathrm{~S}-23 \mathrm{~S}$ internal transcribed spacer (ITS) is commonly used molecular marker as an addition to $16 \mathrm{~S}$ rRNA sequence, because it offers higher resolution 
under the species level. It might be used for phylogeny reconstruction or for an estimation of secondary structures of several semi-conservative helices (e.g. BOYER et al. 2001, 2002).

In this paper, we will present a new genus of Pseudanabaena-like cyanobacteria from periphyton and plankton of the lake Hồ Đâu Co in Vietnam using combination of molecular, ecological and morphological data.

\section{Materials and Methods}

Strain isolation. Samples were collected from plankton and periphyton of a lake Hồ Đâu Co, province Đồng Nai, Vietnam (GPS: $11^{\circ} 28.336^{\prime} \mathrm{N}, 107^{\circ} 20.462^{\prime} \mathrm{E}$, conductivity: 44 2010. Strains were isolated from fresh samples using standard isolation techniques. Two cultures (E5 and E10) were maintained in $90 \mathrm{~mm}$ Petri dishes under the following conditions: temperature $26 \pm 1^{\circ} \mathrm{C}$, illumination $20 \mu \mathrm{mol} . \mathrm{m}^{-2} \cdot \mathrm{s}^{-1}$ light regime $12 \mathrm{~h}$ light/12h dark, and liquid Zehnder mediun

Morphological assessment. Morphology of the strains was nalyzed using a light microscope Zeiss Axiolmager (objectives EC Plan-Neofluar 40×/1.3 N.A., oil immersion, DIC Plan-Apochromat 100×/1.4 N.A., oil immersion, DIC) with a high resolution camera (AxioCam HRc 13MPX). During morphological evaluation strains, the following characters production, sheaths, and granulation of cells.

Strain E5 was cultivated under different physicalchemical parameters in order to describe morphologica variability. The strain was cultivated at $16^{\circ} \mathrm{C}$ and $26^{\circ} \mathrm{C}$ for 14 days in conditions as stated above. For each temperature, four media were prepared: standard $\mathrm{Z}$ medium as a control, nitrogen free $\left.\left(\mathrm{N}^{-\mathrm{NO}_{3}}\right)^{-}\right)$medium, phosphorus free $\left(\mathrm{P}-\mathrm{HPO}_{4}{ }^{2}\right.$ medium, and both nitrogen and phosphorus free medium Measurements were performed on first five cells of 30 filature and nutrients). Analysis of variance (one-way ANOVA) with Tukey's pairwise comparison was performed in PAST 3 (HAMMER et al. 2001).

PCR amplification and sequencing. Genomic DNA was extracted from approximately $50 \mathrm{mg}$ of fresh biomass using bad, CA, USA) following the manufacturs mol, Calsquality and consistence was checked on GelRed (Biotinum Inc., Hayward, CA, USA) stained 1.5\% agarose gel. DNA was quantified using the NanoDrop 1000 (Thermo Fisher Scientific, Wilmington, DE, USA).

The partial 16S rRNA and the whole 16S-23S ITS were obtained using $P C R$ amplification with primers. ward P2 (5 -GGGGAATTTTCCGCAATGGG-3 $3^{\circ}$ ), and reverse P1 (5'-CTCTGTGTGCCTAGGTATCC- $3^{\circ}$ ) previoustotal volume of $40 \mathrm{Hl}$, contained: $17 \mathrm{Hl}$ of sterile water, 1 H of each primer $(0.01 \mathrm{mM}$ concentration $), 20 \mu 1 \mathrm{Fas} S \mathrm{Start} P \mathrm{PCR}$ Master (Roche Diagnostics GmbH, Mannheim, Germany), and $1 \mu \mathrm{l}$ of template DNA $\left(50 \mathrm{ng}, \mathrm{\mu l}^{-1}\right)$. PCR amplificatio was performed with the conditions used before in Dvǒ̆Ák et al. (2012). PCR products were cloned using StrataClone PCR Clonng kit (Agilent Technologies, Stratagene Product Division, La Jolla, CA, USA) fllowng mant actures manuPlaside were in Drorak et al. (2012).

nced using primers $\mathrm{M} 13 \mathrm{f}$ and $\mathrm{M}$ (3). Moreover, two additional interCGCCCGTC- $3^{\circ}$ ), and P8 (5'-AAGGAGGTGATCCAGC CACA-3') (Boyer et al. 2001, 2002). Sequences were assembled and proofread in Sequencher 5.1 (Gene Codes Corporation, Ann Arbor, MI, USA). Sequences were deposnih.gov/), accessio

Phylogenetic analyses. The most similar sequences of $16 \mathrm{~S}$ RNA were retrieved from the NCBI database (http://www ncbi.nlm.nih.gov/) and identified using nucleotide BLAS (http://blast.ncbi.nlm.nih.gov/Blast.cgi). Reference se quences of Pseudanabaena were added. Multiple sequence alignment was performed in MEGA 6 (TAMURA et al. 2013) to the outgroup Gloeobacter violaceus. The most appropriate model for Bayesian inference was determined in jModelTest 0.1.1 (PosADA 2008) based on both the Bayesian and the Akaike Information Criterion as following: F81 mode with gamma distributed variation across sites. 50\% majority consensus tree was constructed in MrBayes 3.2.3 (Ronquis \& HUELSENBECK 2003). Two separate runs were performed each with 3 heated and 1 cold chains for $8,000,000$ genertions. The sampling frequency was each $1000^{\text {th }}$ generation analysis was performed in RaxML 8.0.2 (StAMATAKIS 2006) with a GTRGAMMA model. Maximum parsimony analyses were performed in PAUP* $4.0 b 10$ (SwOFFord 2002), gap were treated as missing data. All analyses were tested using bootstrapping with 1000 replicates.

The secondary structures of D1-D1' helix and Box$B$ helix ITS regions were predicted with the Mfold web serv$\left(37^{\circ} \mathrm{C}\right)$.

\section{Results}

Pinocchia Dvořák, JaHOdáŘová et HašLer gen. nov. Description: Trichomes solitary or in colony (mats), sheath thin, colourless and facultative. Trichomes straight or bent, constricted at cross-walls, motile, 2 to 34 cells. Cells with distinctive centro- and chromatoplasma, cell length significantly varies within filament, cells connected with hyaline bridges, cell content homogenous or with small granules. Terminal cell often elongated and differentiated. Reproduction by disintegration into short filaments (hormogonia) without help of necridic cells.

Etymology: Generic epithet refers to the elongated cells, especially to terminal cells. Pinocchio is a popular character from an Italian fairy tale (by Carlo Collodi), who had longer nose when telling lies.

Type species: Pinocchia polymorpha DvoŘÁ, JAHODÁR̆OVÁ et HAŠLER
Pinocchia polymorpha Dvořá, JAHODÁŘoví et HAŠLER sp. nov.

Description. Trichomes solitary or in colony (mats), sheath thin, colourless and facultative. Trichomes straight or bent, constricted at cross-walls, motile, maximally $75 \mu \mathrm{m}$ long (2 to 34 cells). Cells blue-green, with distinctive centro- and chromatoplasma, facultative polar aerotopes, cells connected with hyaline bridges, cell content homogenous or with small granules, $1.09-2.86 \mu \mathrm{m}$ wide and 1.28-8.63 (12) $\mu \mathrm{m}$ long, cell length significantly varies within filament. Terminal cell often elongated up to $12 \mu \mathrm{m}$, pointed, conical, or rounded. Reproduction by disintegration into short

filaments (hormogonia) without help of necridic cells. Etymology: A species name refers to the fact that a cell length is highly polymorphic in the filaments.

Type locality: Lake Hồ Đâu Co, province Đồng Nai, Vietnam (GPS $11^{\circ} 28.336^{\prime} \mathrm{N}, 107^{\circ} 20.462^{\prime} \mathrm{E}$ ), coll. $\mathrm{E}$ S. Gusev $10^{\text {th }}$ September 2010

Habitat: Plankton and periphyton of freshwater tropical lake.

Iconotype: Fig. 1a.

Holotype: Holotype OLM Botany 24: Lichenes and others No. 9219, dried sample is deposited in Regiona Museum in Olomouc, Czech Republic. Type strain
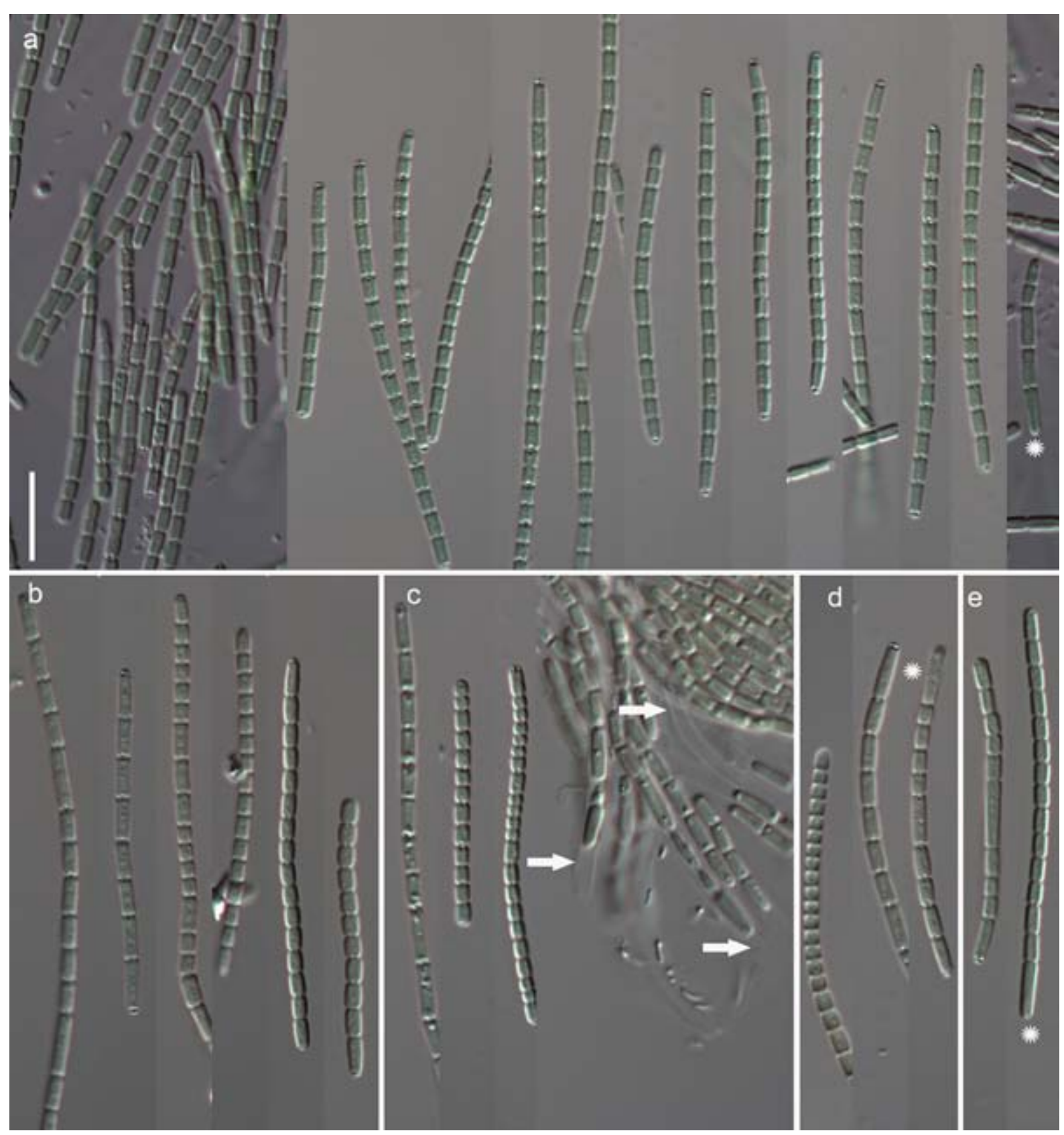

Fig. 1. Pinocchia polymorpha sp. nov: (a) strain $\mathrm{E} 5$ in full $\mathrm{Z}$ medium and $26^{\circ} \mathrm{C}$; (b) the same in medium without nitrogen; (c) the same in medium without phosphorus; (d) the same strain in medium withouth both $\mathrm{N}$
$10 \mu \mathrm{m}$, asterix show elongated terminal cells, arrow show colourless sheath. 
UPOC 62-P/2013, deposited at the culture collection of Department of Botany, Palacký University in Olomouc,Czech Republic.

\section{Morphological observations}

Cell length and width varied significantly among filaments measured in different culture conditions. The maximum cell length $(8.63 \mu \mathrm{m})$ was observed in medium without nitrogen in $26{ }^{\circ} \mathrm{C}$. On the other hand, the shortest cell $(1.28 \mu \mathrm{m})$ was observed in medium without phosphorus in $16^{\circ} \mathrm{C}$. The widest cell $(2.86$ $\mu \mathrm{m})$ in medium without nitrogen and the narrowes cells $(1.09 \mu \mathrm{m})$ occurred in standard $\mathrm{Z}$ medium (in 26 ${ }^{\circ} \mathrm{C}$ ), and without phosphorus (in $26^{\circ} \mathrm{C}$ ) respectively. An ANOVA test revealed significant differences $(\mathrm{p}<$ 0.01 ) only among cultures maintained in $26^{\circ} \mathrm{C}$ (Table 1). Tukey's test showed significant difference ( $p<$ 0.01 ) in variance of cell length/width ratio among all compared measurements except control culture versus culture without phosphorus, and control versus culture without both nitrogen and phosphorus. Polymorphism in cell length is demonstrated in Fig. 1. Filaments with short cells and with both short and long cells were frequent particularly in cultures limited by nutrients frelow temperature (Fig. 1b).

\section{Phylogeny}

6S rRNA phylogeny based on Bayesian inference revealed that strains of Pinocchia polymorpha form a monophyletic lineage among other filamentous cyanobacteria of genera Leptolvngbya, Trichocoleus, Pseudanabaena, and Nodosilinea (Fig. 2). The Pinocchia

Table 1. Results of ANOVA analysis and Tukey's test for both studied temperatures. Right upper triangle represents probabilities and
lower left triangle represents Studentize Range Statistics Q [(C) lower left triangle represents Studentize Range Statistics $Q$
control medium, (N) medium without nitrogen, (P) medium withou control medium, (N) medium without nitrogen, (P) medium withou
phosphorus, and (NP) medium without phosphorus and nitrogen].

\begin{tabular}{ccccc}
\hline $\begin{array}{c}\text { Tukey's test } \\
\mathbf{1 6}^{\circ} \mathbf{C}\end{array}$ & $\mathbf{C}$ & $\mathbf{N}$ & $\mathbf{P}$ & $\mathbf{N P}$ \\
\hline $\mathrm{C}$ & & 0.4404 & 0.6064 & 0.6723 \\
$\mathrm{~N}$ & 2.114 & & 0.9936 & 0.04327 \\
$\mathrm{P}$ & 1.742 & 0.3719 & & 0.08497 \\
$\mathrm{NP}$ & 1.595 & 3.709 & 3.337 & \\
\hline
\end{tabular}

ANOVA: $p=0.0333, F=2.924$

\begin{tabular}{ccccc}
\hline $\begin{array}{c}\text { Tukey's test } \\
\mathbf{2 6}^{\circ} \mathbf{C}\end{array}$ & $\mathbf{C}$ & $\mathbf{N}$ & $\mathbf{P}$ & $\mathbf{N P}$ \\
\hline $\mathrm{C}$ & & $7.72 \mathrm{e}^{-6}$ & 0.3865 & 0.6924 \\
$\mathrm{~N}$ & 9.776 & & $8.23 \mathrm{e}^{-6}$ & $7.72 \mathrm{e}^{-6}$ \\
$\mathrm{P}$ & 2.243 & 7.532 & & 0.03684 \\
$\mathrm{NP}$ & 1.549 & 11.32 & 3.792 & \\
\hline ANOVA: $\mathrm{p}=2.33 \mathrm{e}^{-15}, \mathrm{~F}=25.2$ & & &
\end{tabular}

clade had 100 bootstrap and posterior probability support. Five closest relatives identified by BLAST we Leptolyngbya sp. Kovacik 1990/37 (EU528671), an four strains of Trichocoleus desertorum (described by MüHLSTEINOVA et al. 2014). However, none of thes strain belonged to the same monophyletic cluster of Pinocchia.

The Pseudanabaena sensu stricto formed monophyletic clade near a root of the phylogenetic tree (Fig. 2), thus distant to Pinocchia. There was also noticeable variability within the clade of Pinocchia. Clones were divided into two groups, however ambiguous, with low bootstrap support.

\section{Secondary structures of $16 \mathrm{~S}-23 \mathrm{~S}$ ITS}

The strain E5 contained likely two ribosomal operons. Although it contained no tRNAs, two of five clones contained identical inserts at position 553 to 567 . The topology of DI-DI' and Box-B helices were identical among all sequenced clones (Fig. 3). Strain E10 had at least two ribosomal operons, one containing tRNA coding isoleucine and one with missing tRNA. Estimated secondary structures of the ITS of Pinocchia strain E10 exhibited considerable variability and significantly differed among clones (Fig. 3). However, pattern of DI-DI as well as Box-B helices was congruent within the clones that contained and missing RNA. An operon with tRNA had the D1-D1' significantly longer $(118 \mathrm{bp}$ ) than the operon without tRNA with size of 53 bp. They also exhibited significantly different topology (Fig. 3). Moreover, Dl-D1' helices were largely dissinilar betwen studied strans considering both length and shape. On the other hand, Boxhelices were similar among clones and also betwee

\section{Discussion}

Molecular techniques have allowed researchers to uncover reticulate evolutionary histories among cyanobacteria (see KomÁreK 2010 for review). Most of the traditional Geitlerian genera have been shown polyphyletic, resulting in an assumption of the existence of cryptogenera (KoMÁREK et al. 2014). Cryptogener are evolutionary lineages among cyanobacteria which possess similar (often unrecognizable) morphology, but they are usually polyphyletic based on analysis of phylogeny usually of $16 \mathrm{~S}$ rRNA. It has been suggested that this phenomenon is connected with frequen convergent evolutionary events among cyanobacteria (DvoŘÁK et al. 2014a).

Such an example of a cryptogenus is presented in this paper. The newly established genus Pinocchia would be identified to the genus Pseudanabaen based solely on morphology as reviewed in KOMÁreK \& AnaGnostidis (2005). However, phylogenic reconstruction using $16 \mathrm{~S}$ rRNA sequence data showed Pseu-

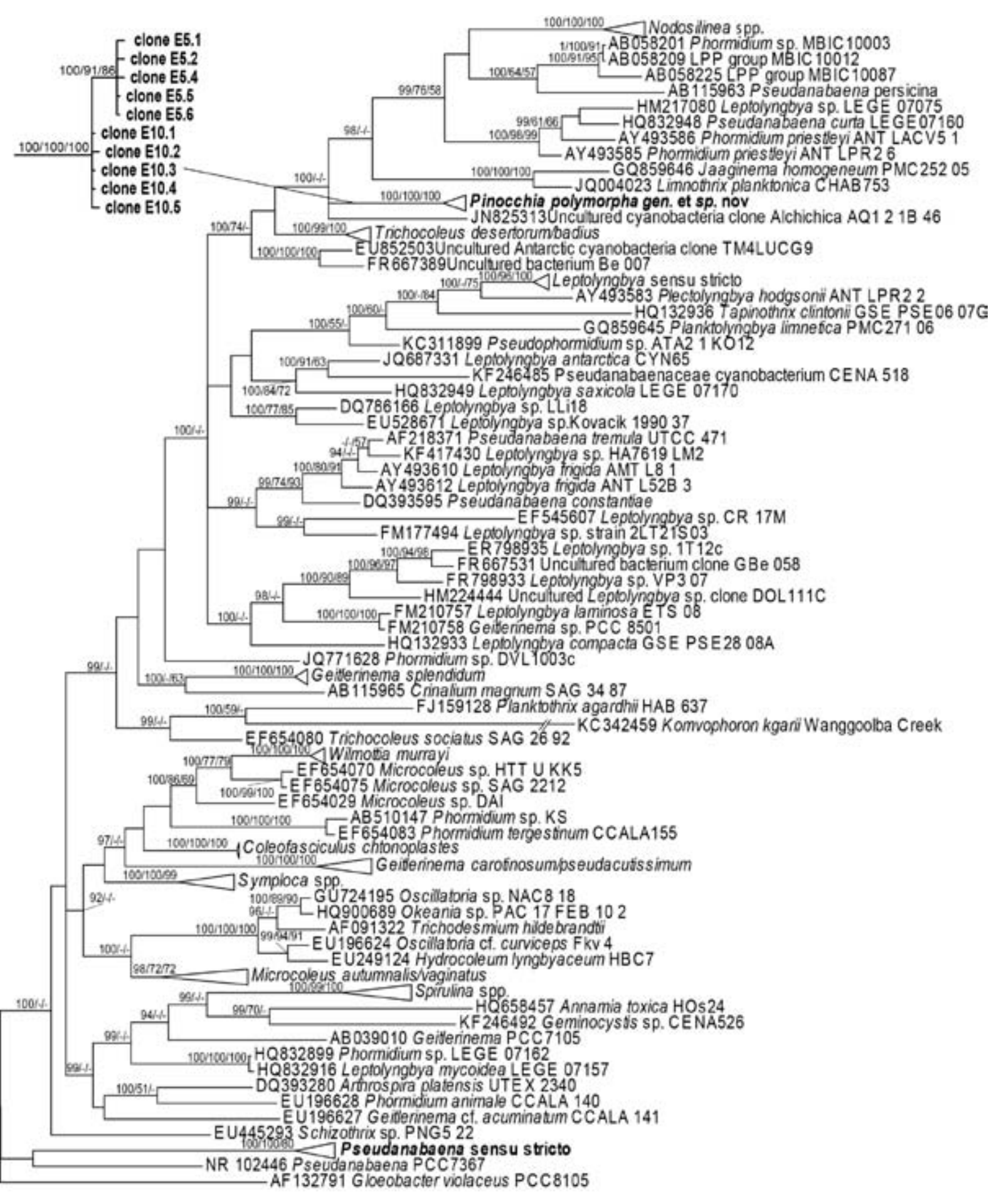

$\overline{0.05}$

iig. 2. A phylogenetic reconstruction based on $16 \mathrm{~S}$ rRNA using Bayesian inference. Studied strains and Pseudanabaena sensu stricto are probabilities $>90$. A collapsed cluster of $P$ Pinocchia is unfolded aside of the tree.

danabaena to be polyphyletic. A clade of Pinocchia is far from Pseudanabaena sensu stricto clade (with type species P. catenata) situated near the root of the tree (Fig. 2).

recently published phylogenies (e.g. PerKerson et al. 2011; DaGAN et al. 2013; KomÁreK et al. 2014) in a sense that there are formed same monophyletic clusters representing genera (e.g. Wilmottia, Nodosilinea, and Pseudanabaena sensu stricto). A position of higher 

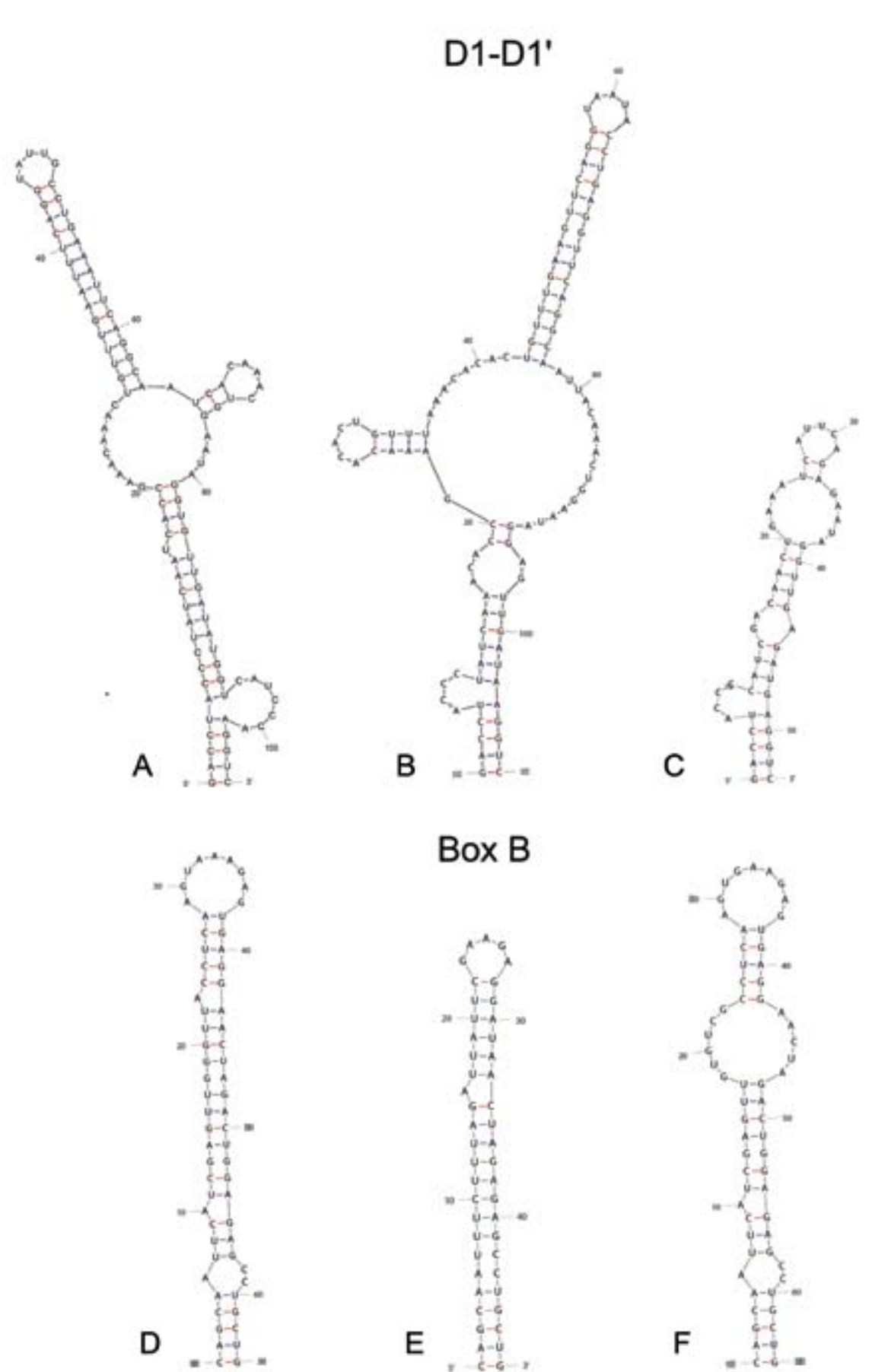

Box B
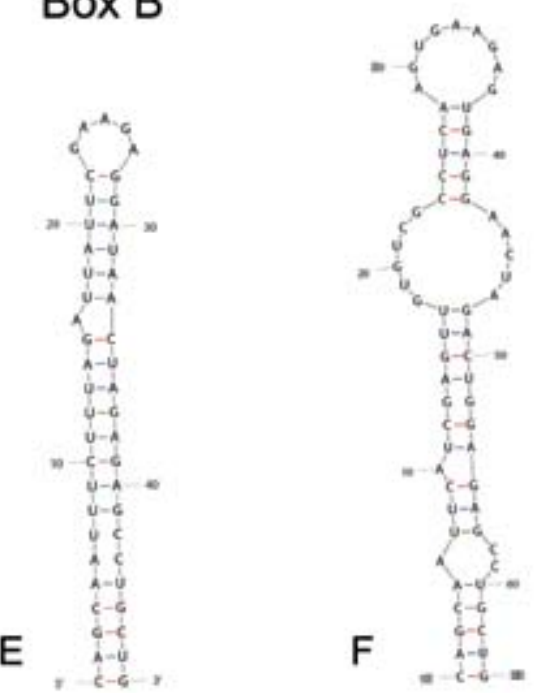

ig. 3. Estimated 16S-23S ITS secondary structures D1-DI' and Box-B helices or Pinocchia: (A, D) for clones E5.1, E5.2, E5.4, E5.5, ES.6, (B, E) for clones E10.1, E10.3; (C, F) for clones E10.2, E10.4, E10.5

taxonomical groups seems to be more reticulate. For instance, the family Gomontiellaceae sensu KOMAREK et al. (2014) is not monophyletic in our phylogenetic analysis (Fig. 2) because Crinalium is not in the same clade as Komvophoron. Further, the order Synechococcales also appears to be polyphyletic too (Fig. 2), because members of family Pseudanabaenaceae (e.g. Pseudanabaena) and Leptolyngbyaceae (e.g. Nodosi linea) do not form related clusters. However, none of these studies (including ours) had complete taxon sampling 16S rRNA sequences, thus they cannot present complete view on cyanobacterial evolution.

Komárek et al. (2014) has recently proposed a new classification of higher taxonomical units in cyanobacteria. Based on their criteria and phylogenetic position, Pinocchia may be classified to the family eptolyngbyaceae, order Synechococcales.

Based on morphological criteria Pinocchia is similar to the genus Pseudanabaena, and particularly, to its subgenus Ilyonema sensu КомÁREK \& ANAGNOSTIDIS (2005), which is also characterized by pola aerotopes and shape of terminal cells. The most simila morphotype to Pinocchia from the subgenus Ilyonema is I. galeata, but Pinocchia possesses high variability of cell length among cells within a filament, which is rather characteristic for P. catenata (KOMAREK \& ANAGNostidIs 2005, Fig. 1). Furthermore, Pinocchia slightly differs from I. galeata with prolonged, pointed and sometimes conical terminal cell, although I. galeata has sometimes rounded-conical terminal cell (КомÁREK \& ANAGNostidis 2005). Pinocchia is also slightly wider $(2.84 \mu \mathrm{m})$ than I. galeata $(2.7 \mu \mathrm{m})$. Therefore, together with its tropical origin and phylogenetic position, we suggest that Pinocchia may be designed as a new monospecific genus.

16S-23S ITS secondary structures are powerful tools for identification of taxa at or below the species level (e.g. BoyER et al. 2001; HAŠLER et al. 2014 Osorio-SANTOS et al. 2014 and many others). We found high variability among clones and between both isolated strains (Fig. 3). The difference between D1-D1 helices and Box-B helices among two strains was significant (Fig. 3.), which might suggest existence of two cryptic species in Pinocchia, because a morphology was congruent between strains. However, we will need to find more strains in future to resolve these enigmatic relationships within Pinocchia.

Significant differences were found among culures of Pinocchia maintained in $26^{\circ} \mathrm{C}$ in media lacking phosphorus, nitrogen or both. Therefore, nitrogen an phosphorus (or N/P ratio) significantly influence cell length (Table 1), more likely due to influence of intensity of cell division, which has been shown before in other microalgae (LUKAVSKÝ 1973; PouličKová et al. 2001; Dŕímalová \& PouličKová 2003; Hašler et al 2003; HašLER \& PoulíčKová 2010). Higher temperatures seem to be more convenient for Pinocchia, probably due to the isolation from the tropical lake. Thus, we suppose that results retrieved from $26^{\circ} \mathrm{C}$ resemble more natural conditions. Although these morphological experiments are not at all exhaustive, we do not suppose that future investigation (of pH, light or other parameters) will reveal new morphological feature, which will be able to distinguish Pinocchia from the other Pseudanabaena-like cyanobacteria more reliably. Such a little morphological plasticity for identifiin polyphyletic genera with very simple morphology such as Synechococcus (DvoŕAK et al. 2014b) and Leptolynbya (Osorio-SAntos et al. 2014).

Taken together, Pinocchia represents another example of a cryptogenus derived from polyphyletic Pseudanabaena, which seem to be very frequen among cyanobacteria (KOMAREK et al. 2014) and exemplified in the genus Synechococcus (Dvoř́́K et al. 2014a,b). The cryptogenus is very important consideration for taxonomist and ecologist interested in cyanobacteria, because only morphological criteria appear to be unsufficient to recognize distant evolutionary lineages.
ACKNowLEDERMENTS

We would like to thank to Dr. Lubor Kysučan (Palacký University ude to Dr. Dale A. Casamatta (University of North Florida, Jacksonville, FL, USA), who edited English throughout the manuscript. This study was supported by BSF Post-UP IS CZ.1.072.3.00/30.004 $14-14-00555$

\section{REFERENCES}

Acinas, S.G.; Haverkamp, T.H.A.; Huisman, J. \& Stal, L.J. (2009): Phenotypic and genetic diversification of 31-46.

BOYER, S.L.; FLeTChNER, V. \& JOHANSEN, J.R. (2001): Is the 16S-23S rRNA internal transcribed spacer (ITS) region a good tool for use in molecular systematics and population genetics? A case study in cyanobacteria. - Mol. Biol. Evol. 18: 1057-1069.

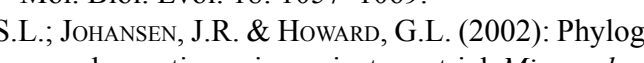
eny and genetic variance in terrestrial Microcoleus (Cy thophyceae) species based on sequence analys
of thNA gene and associated 16S-23S ITS

region. - J. Phycol. 38: 1222-1225.
Dagan, T.; RoetTGER, M.; StuckeN, K.; LANDAN, G.; Koch, R.; MAJOR, P.; GouLD, S.B.; GoREMYKIN, V.V.; RIPPKA, R.; TANDEAu de Marsac, N.; Gugger, M.; LockharT, P.J.; AlLEN, J.F.; BRUNE, I.; MAUS, I.; PÜHLER, A. \& MARTIN, W.F. (2012): Genomes of stigonematalea oxygenic photosynthesis form prokaryotes to plo tids. - Genome Biol. Evol. 5: 31-44.

DŔimaloví, D. \& Poulič́ovó, A. (2003): Filament fragmentation of Klebsormidium flaccidum. - Biologia 58 525-527.

DVoŔak, P.; Casamatta, D.A.; Hašler, P.; ONDǨ́e, V.; Poulič́roví, A. \& SAnges, R. (2014a): Synechococ cus: 3 billion years of global dominance. - Mol. Eco

作 from three continents - vaginatus (cyanobacteria) characterization. - PLoS ONE7: e40153. doi:10.1371/journal.pone. 0040153

Dvořá, P.; Hindák, F.; Hašler, P.; Hindáková, A. \& PouLičKoví, A. (2014b): Morphological and molecular studies of Neosynechococcus sphagnicola, gen. sp. nov. (Cyanobactera, Synechococtales). - Phyto-
taxa 170: 24-34.

EDGAR, R.C. (2004): MUSCLE: multiple sequence alignme with high accuracy and high throughput. - Nucleic Acids Res. 32: 1792-1797.

Geitrer, L. (1932): Cyanophyceae. - In: Kolkwitz, R. (ed.) Rabenhorst's Kryptogamenflora, vol. 14. - 1196 pp

J.F., SANT 'ANNA, C.L.; AZEVEDO, M.T.P.; KOMÁRER, J.; KAŠTOVSKYY, J.; SULEK, J. \& LORENZI, A.S. (2007)
The cyanobacterial genus Brasilonema - molecul and phenotype evaluation - J Phycol 43: 789-798

Hammer, Ø.; Harper, D.A.T. \& Ryan, P.D. (2001): PAST: Paleontological statistics software package for edu-
cation and data analysis. - Palaeontologia Electron- 
ica 4: 9.

Hašler, P.; Dvořák, P.; Poulíč́ová, P. \& Casamatta, D.A. (2014): A novel genus Ammassolinea gen. nov. (Cyanobacteria) isolated from sub-tropical epipelic habitats. - Fottea 14: 241-248.

HašLER, P. \& PoulíčKovÁ, A. (2010): Diversity, taxonomy and autecology of autochtonous epipelic cyanobacteria of the genus Komvophoron (Borziaceae, Oscillatoriales): a study on populations from the Czech Republic and British Isles. - Biologia 65: 7-16.

Hašler; P.; PoulíčKovÁ, A. \& VAŘ́eKovÁ, Š. (2003): Comparative studies on two strains of the genus Planktothrix (Cyanophyta, Cyanoprokaryota). - Algological Studies 108: 31-43.

KomÁReK, J. (2010): Recent changes (2008) in cyanobacteria taxonomy based on a combination of molecular background with phenotype and ecological consequences (genus and species concept). - Hydrobiologia 1: 245-259.

KomÁreK, J. \& AnAgnostidis, K. (2005): Cyanoprokaryota. 2. Teil: Oscillatoriales. - In: BÜDEL, B.; GÄRDNER, G.; Krienitz, L. \& Schagerl. M. (eds): Süswasserflora von Mitteleuropa, vol. 19/2. - 759 pp., Elsevier, München.

KomáReK, J.; Kaštovský, J.; Mareš, J. \& Johansen, J.R. (2014): Taxonomic classification of cyanoprokaryotes (cyanobacterial genera) 2014 using a polyphasic approach. - Preslia 86: 295-335.

LAUTERBORN, R. (1915): Die sapropelishe Lebewelt. (Ein Beitrag zur Biologie des Faulschlammes natürlicher Gewässer). - Verh. Naturhist.-mediz. Ver. Heidelberg N.F. 13: 395-481.

LuKAVSKÝ, J. (1973): Degree of synchrony in natural algal populations. - In: HeJnÝ, S. (ed.): Ecosystem study on wetland biome in Czechoslovakia, Czechosl. IBP Report 3. - pp. 213-217, Czechoslovak Academy of Sciences, Czechoslovak National Committee for the Internatioanl Biological Programme, Třeboň.

Mühlsteinová, R.; Johansen, J.R.; Pietrasiak, N.; Martin, M.P.; Osoirio-SAntos, K. \& WarRen, S.D. (2014): Polyphasic characterization of Trichocoleus desertorum sp. nov. (Pseudanabaenales, Cyanobacteria) from desert soils and phylogenetic placement of the genus Trichocoleus. - Phytotaxa 163: 241-261.

Osorio-Santos, K.; Pietrasiak, N.; Bohunická, M.; MisCoe, L.H.; KovÁciK, L.; Martin, M.P. \& Johansen, J.R. (2014): Seven new species of Oculatella (Pseudanabaenales, Cyanobacteria). - Eur. J. Phycol. 49: $450-470$

Perkerson, R.B.; Johansen, J.R.; KováČIK, L.; Brand, J.; KaštovskÝ, J. \& Casamatta, D.A. (2011): A unique pseudanabaenalean (cyanobacteria) genus Nodosilinea gen. nov. based on morphological and molecular data. - J. Phycol. 47: 1397-1412.

Polz, M.F.; Alm, E.J. \& Hanage, W.P. (2013): Horizontal gene transfer and the evolution of bacterial and archeal population structure. - Trends Genet. 29: $170-175$.

PosadA, D. (2008): jModelTest: phylogenetic model averaging. - Mol. Biol. Evol. 25: 1253-1256.

PoulíčKovÁ, A.; Dřímalová, D.; NovotnÝ, R.; VÁlová, P. \& HaVráneK, P. (2001): Morphological responses to varying environmental conditions in Klebsormidium flaccidum isolated from Moroccan desert soils. Nova Hedwigia 123: 397-409.
Ronquist, F. \& HuELSENBECK, J.P. (2003): MRBAYES 3: Bayesian phylogenetic inference under mixed models. - Bioinformatics 19: 1572-1574.

Stamatakis, A. (2006): RAxML-VI-HPC: maximum likelihood-based phylogenetic analyses with thousands of taxa and mixed models. - Bioinformatics 22: 26882690.

Staub, R. (1961): Research on physiology of nutrients of the planktonic cyanobacterium Oscillatoriarubescens. - Schweizerische Zeitschrift fur Hydrologie 23: $83-198$

Swofford, D.L. (2002): PAUP*: Phylogenetic Analysis Using Parsimony (*and other methods), version 4. Sunderland, MA: Sinauer Associates.

Tamura, K.; Stecher, G.; Peterson, D.; Filipski, A. \& KuMAR, S. (2013): MEGA6: Molecular Evolutionary Genetics Analysis Version 6.0. - Mol. Biol. Evol. 30: 2725-2729.

VACCARINo, M.A. \& Johansen, J. R. (2011): Scytonematopsis contorta sp. nov. (Nostocales), a new species from the Hawaiian Islands. - Fottea 11: 149-161.

Whitton, B.A. \& Potтs, M. (2000): The ecology of cyanobacteria. Their diversity in time and space. $-669 \mathrm{pp}$., Springer, Berlin.

ZuCKER, M. (2003): Mfold web server for nucleic acid folding and hybridization prediction. - Nucleic Acids Res.31: 3406-3415.

Supplementary material

the following supplementary material is available for this article:

Table S1. Taxa with accession numbers from GenBank database used in the phylogenetic analysis.

Dataset 1. Multiple sequence alignment used in the $16 \mathrm{~S}$ rRNA phylogenetic analysis in nexus format.

This material is available as part of the online article (http://fottea.czechphycology.cz/contents)

(C) Czech Phycological Society (2015)

Received December 21, 2014

Accepted February 5, 2015 